\title{
Factors associated with uptake, adherence, and efficacy of hepatitis $C$ treatment in people who inject drugs: a literature review
}

This article was published in the following Dove Press journal:

Patient Preference and Adherence

16 October 2013

Number of times this article has been viewed

\author{
Viktor Mravčík ${ }^{1,2}$ \\ Lisa Strada ${ }^{3}$ \\ Josef Štolfa ${ }^{4,5}$ \\ Vladimir Bencko ${ }^{6}$ \\ Teodora Groshkova ${ }^{7}$ \\ Jens Reimer ${ }^{3}$ \\ Bernd Schulte ${ }^{3}$ \\ 'National Monitoring Centre \\ for Drugs and Drug Addiction, \\ ${ }^{2}$ Department of Addictology, \\ First Faculty of Medicine, Charles \\ University in Prague, Prague, Czech \\ Republic; ${ }^{3}$ Centre for Interdisciplinary \\ Addiction Research, University \\ of Hamburg, Hamburg, Germany; \\ ${ }^{4}$ Department of General Practice, \\ Institute for Postgraduate Medical \\ Education in Prague, ${ }^{5}$ Department \\ of General Practice, Second Faculty \\ of Medicine, ${ }^{6}$ Institute of Hygiene \\ and Epidemiology, First Faculty of \\ Medicine, Charles University in \\ Prague, Prague, Czech Republic; \\ ${ }^{7}$ European Monitoring Centre for \\ Drugs and Drug Addiction, Lisbon, \\ Portugal
}

Introduction and methods: Hepatitis $\mathrm{C}$ virus (HCV) infections are highly prevalent amongst people who inject drugs (PWID). Despite well documented evidence of its effectiveness, suggested cost-effectiveness, and potential to reduce HCV prevalence rates, the uptake of antiviral HCV treatment by PWID is low. This nonsystematic literature review describes factors associated with the uptake, adherence, and efficacy of HCV treatment among PWID and discusses strategies to increase their uptake of treatment.

Results: Low HCV treatment uptake among PWID is associated with a number of patientrelated and provider-related barriers. Beliefs and fears about low efficacy and adverse effects on the patient's part are common. A substantial number of factors are associated with the chaotic lifestyle and altered social functioning of PWID, which are often associated with decompensation or relapsing into drug addiction. This may lead to perceived low adherence with treatment and low efficacy on the provider's part too, where lack of support, inadequate management of addiction, and other drug-related problems and poor treatment of side effects have been described. Practical issues such as the accessibility of treatment and finances also play a role. Strategies to improve the HCV treatment rate among PWID involve pretreatment management and assessment, a multidisciplinary approach, management of side effects, and enhanced education and counseling.

Conclusion: Specific factors are associated with poorer treatment outcomes in PWID on the side of both the patient and the treatment system. However, given that PWID can achieve treatment adherence and sustained virologic response rates comparable with those in nondrug users, drug use per se should not be considered a criterion for exclusion from treatment. Further development of measures leading to higher uptake of treatment and adherence in PWID and appropriate adaptation of HCV treatment guidelines represent important tools in this regard.

Keywords: hepatitis C virus, people who inject drugs, treatment uptake, adherence, efficacy

\section{Introduction}

With more than 185 million people infected worldwide, hepatitis $\mathrm{C}$ is a global public health concern. ${ }^{1-3}$ While iatrogenic exposure, such as unsafe therapeutic injecting practices, is responsible for the majority of hepatitis $\mathrm{C}$ virus (HCV) transmissions in developing countries, injecting drug use is the predominant risk factor in Western industrialized cultures. ${ }^{4-7}$ The prevalence of HCV antibodies among people who inject drugs (PWID) varies between countries, with the rates being from $40 \%$ to $90 \%{ }^{8-10}$ Worldwide, between 6 and 15 million PWID are infected with the virus, ${ }^{9}$ and with around 350,000 deaths per year, HCV is an increasing cause of morbidity and mortality. ${ }^{11}$

Despite the fact that PWID represent the majority of $\mathrm{HCV}$-infected individuals in developed countries, their uptake of treatment is generally considered to be low. ${ }^{12-15}$
Correspondence: Viktor Mravčík National Monitoring Centre for Drugs and Drug Addiction, Office of the Government of the Czech Republic, Nábřeží E Beneše 4, II8 0 I Prague I, Czech Republic

Tel +420296 I53 354

Fax +420296 I53 264

Email mravcik.viktor@vlada.cz 
This nonsystematic literature review focuses on uptake of HCV treatment, as well as adherence with it and efficacy of treatment in PWID, and identification of associated factors. Following that, strategies for augmenting the uptake of HCV treatment are reviewed and discussed.

\section{Clinical aspects and natural course of HCV infection}

The course of acute HCV infection is variable and in most cases asymptomatic. As a result of the mainly unspecific, often fatigue-like or flu-like symptoms, early detection and assessment of $\mathrm{HCV}$ infection remains a challenge, especially given that not all patients show elevated transaminases. In acute infection, spontaneous eradication of the virus is possible; clearance is reported for $20 \%-50 \%$ of those who are infected. ${ }^{16-18}$ A number of host and virus factors have been described as predictors of spontaneous HCV clearance, such as host genetics (IL28B genotype, HLA type), female sex, nonblack ethnic origin, an innate and adaptive robust immune response, virus-specific neutralizing antibodies, HCV genotype, chronic hepatitis B virus (co)infection, and human immunodeficiency virus-negative status. ${ }^{19}$

In the absence of spontaneous clearance within 6 months, $\mathrm{HCV}$ infection is considered to be chronic, leading to liver cirrhosis in $8 \%-45 \%$ of infected individuals..$^{20,21}$ Similar rates have been found in a recent meta-analysis of 47 published papers, in which the estimated rate of progression to cirrhosis in PWID was 8.1 per 1,000 person-years, which corresponds to a mean estimate of $14.8 \%$ in 20 years. ${ }^{22}$ Cirrhosis can result in hepatic decompensation and liver cancer, with a peak incidence at around 30 years after infection. ${ }^{11,21,23}$ This signifies that individuals who were infected with HCV in the 1970s and 1980s are now at high risk of HCV-related liver disease and mortality. ${ }^{24}$ It is therefore of vital importance to increase treatment uptake in order to reduce the number of liver disease-related deaths.

\section{HCV prevention and treatment options}

To begin, we review the options for HCV prevention and how these are relevant to treatment uptake and efficacy. There is a very high genetic variability of $\mathrm{HCV}$, with six main genotypes and 80 subtypes. This variability is the main reason for the difficulties encountered in development of a vaccine, because it must be effective in all genotypes. The genetic variability is of clinical significance regarding treatment efficacy. Rates of sustained virologic response, assessed 6 months after the end of treatment, range between $45 \%$ and $54 \%$ in
HCV genotype 1 and between $65 \%$ and $82 \%$ in genotypes 2 and 3 , with a slightly higher sustained virologic response in genotype $2 .^{25-28}$ This has led to different durations of treatment depending on the virus genotype, ie, 24 weeks for genotypes 2 and 3, and 48 weeks for genotypes 1 and 4. ${ }^{6,29,30}$ Shorter or longer treatment regimens adjusted to the patient's individual viral response can be used. ${ }^{31-33}$ Thus, greater treatment efficacy can be achieved through the individualization of treatment regimes. The most reliable predictor of the efficacy of treatment is measurement of viral kinetics in the first 12-24 weeks of treatment. Negative HCV-RNA in week 4 indicates a high chance of a sustained virologic response. On the contrary, if the decrease in HCV-RNA in week 12 (early virologic response) is lower than $2 \log (10)$, the probability of a sustained virologic response is only $0 \%-3 \%{ }^{34,35}$ Other important predictors of the efficacy of treatment, besides $\mathrm{HCV}$ genotype, are genetic polymorphism in IL28B and the stage of liver fibrosis. ${ }^{28,36}$

There is substantial evidence that opiate substitution treatment reduces the risk of $\mathrm{HCV}$ transmission among PWID, ${ }^{37,38}$ and a further risk reduction can be achieved by simultaneous participation in needle and syringe programs and opiate substitution treatment. ${ }^{39,40}$ Nonetheless, data on the effectiveness of opiate substitution treatment and needle and syringe programs for primary prevention of hepatitis $\mathrm{C}$ infection and subsequent modeling show that these interventions do not necessarily lead to substantial reductions in $\mathrm{HCV}$ prevalence. Statistical modeling for both interventions ( $40 \%$ baseline chronic HCV prevalence) shows that they are unlikely to considerably reduce chronic $\mathrm{HCV}$ prevalence after 10 years unless the intervention coverage is increased by over half, being up to $80 \%$ in opiate substitution treatment and $100 \%$ in needle and syringe programs. ${ }^{41,42}$

Interestingly, recent modeling analyses show a strong preventive potential of $\mathrm{HCV}$ treatment in PWID, since the risk of $\mathrm{HCV}$ transmission decreases with lower HCV prevalence. ${ }^{43,44}$ This primary prevention effect of HCV treatment is larger in populations with a lower baseline HCV prevalence. ${ }^{45,46}$ Even for low treatment rates, a large reduction in HCV at the population level can be achieved. ${ }^{47}$ In addition, statistical modeling suggests that HCV treatment of active injecting drug users is the most cost-effective policy option when chronic $\mathrm{HCV}$ prevalence among PWID is below $60 \%$ (about $80 \%$ antibody prevalence). This effect remains stable even if the sustained virologic response in active injecting drug users is half of that found in non/ex-users. ${ }^{48}$ Furthermore, it has been estimated that $\mathrm{HCV}$ treatment in all infected patients in 2010 could 
reduce the risk of cirrhosis, liver decompensation, cancerrelated, and liver-related deaths by $16 \%, 42 \%, 31 \%$, and $36 \%$ in the course of 20 years, respectively. ${ }^{21}$ In conclusion, the evidence suggests that increasing treatment uptake by active users may be an effective method of reducing the carrier pool and preventing spread of the virus.

\section{Treatment uptake and barriers}

In order to increase treatment uptake, it is important to understand the current barriers to recruitment into treatment. They can be categorized as system-related, patient-related, and provider-related factors.

Different studies point towards a higher potential for treatment uptake within specific referral settings. These are considered system-related factors. A high HCV treatment uptake rate of approximately $20 \%-30 \%$ was found among active PWID referred to an HCV treatment clinic, who were receiving opioid replacement treatment, peer support, and/or multidisciplinary care. ${ }^{49-52}$ An even greater uptake of $\mathrm{HCV}$ treatment (76\%) was reported among PWID to whom HCV treatment was offered and who were eligible on the basis of positive HCV RNA. ${ }^{53}$ On the other hand, when PWID are systematically excluded from HCV treatment because of active or recent drug use, uptake is low. This is evident in Budapest, Hungary, and Bratislava, Slovakia, where abstinence stipulated as a prerequisite for $\mathrm{HCV}$ treatment in national guidelines or health insurance schemes represented a considerable barrier to uptake of treatment. ${ }^{54,55}$ Nevertheless, studies show that the uptake and success of treatment can be achieved in spite of active or recent drug use. In an Amsterdam-based cohort, 30\% of $\mathrm{HCV}$-infected drug users started treatment, although almost all had used illicit drugs 6 months before treatment, 19\% were actively injecting, 62\% used alcohol, and 41\% suffered from psychiatric comorbidity. From the 58 patients recruited into treatment, 57 had sufficient adherence and 37 (65\%) achieved a sustained virologic response. ${ }^{50}$ Similarly, a Canadian study reported a high treatment uptake rate $(51 \%)$ and a high sustained virologic response rate (67\%) despite ongoing drug use during treatment in $75 \%$ of the patients. ${ }^{56}$ Clinicians can adopt a harm reduction approach and tolerate illicit drug use during treatment as long as the therapeutic regime is adhered to. ${ }^{57}$ Thus, treatment of active drug users is possible, and active drug users can achieve high levels of uptake of treatment, as well as adherence with it. On the other hand, external factors that stigmatize, discriminate against, or even police drug users represent substantial barriers to uptake of treatment and adherence with it. ${ }^{58,59}$
$\mathrm{HCV}$ treatment uptake is further affected by patient-related factors, ie, barriers to treatment as experienced by PWID. The low treatment uptake rate $(6 \%)$ among HCV-infected drug users in Baltimore, MD, USA, was associated with treatment-related perceptions and a low perceived need for treatment. ${ }^{12}$ A lack of motivation may also be responsible for a low treatment uptake rate. ${ }^{55}$ Human immunodeficiency virus coinfection can reduce the uptake of treatment and adherence with it, as well as the efficacy of treatment. ${ }^{60,61}$ Adverse effects of HCV treatment may also hamper uptake and adherence, although new medication increases the efficacy of treatment. The current standard treatment for chronic HCV infection is a combination of pegylated interferon $\alpha$ (PEG-IFN) and ribavirin. In 2011, two directly acting antivirals, ie, the protease inhibitors telaprevir and boceprevir, were introduced for the treatment of HCV genotype 1 in combination with PEG-IFN and ribavirin. Adding either of these medications to PEG-IFN and ribavirin leads to higher sustained virologic response rates compared with standard dual treatment (up to 75\%), although with a possible higher rate of adverse effects, such as rash or anemia, and with higher treatment costs. Moreover, new directly acting antivirals administered in interferon-free regimens for a shorter duration and show higher efficacy, better tolerance, and fewer side effects, should be available in the near future. ${ }^{62-64}$ Interestingly, in this context, a positive effect of modest cannabis use in reduction of side effects of $\mathrm{HCV}$ treatment, higher adherence, and a higher sustained virologic response has been reported. ${ }^{57,65}$

Finally, providers are often reluctant to provide HCV treatment to active injecting drug users. ${ }^{66,67}$ One of the clinician-related barriers to treating PWID is fear of relapse into drug injecting and consequent $\mathrm{HCV}$ reinfection after successful HCV treatment. For example, 75\% of clinicians treating $\mathrm{HCV}$ in the Czech Republic preferred nonusers to active drug users for inclusion in treatment, which was even more relevant when financial limitations on treatment were reported by $60 \%$ of treatment centers. ${ }^{68}$ However, a persistent, sustained, virologic response rate and a low reinfection rate of $3 \%-5 \%$ were found, even in those who continued or relapsed into drug injecting. ${ }^{69,70}$ These findings support the assumption of a low reinfection rate in PWID after a sustained virologic response, even if they continue to inject drugs. ${ }^{71}$

\section{Treatment adherence and efficacy}

One of the most important reasons for low HCV treatment uptake in PWID is the assumption of reduced adherence with the treatment regimen leading to poorer treatment outcomes, although the relationship between adherence and outcome 
seems to be complex. ${ }^{72}$ Nonadherence in HCV treatment may refer to both dose reduction and early discontinuation of treatment, with the latter probably having a stronger impact on reduced sustained virologic response. ${ }^{73,74}$ Contrary to expectations, PWID do not differ from nondrug users in their adherence to treatment (eg, for tuberculosis, acquired immune deficiency syndrome, and hepatitis B virus vaccination), with rates ranging between $30 \%$ and nearly $100 \%$. In programs specifically designed for drug users, adherence often exceeds $80 \% .^{71}$ The following studies exemplify that PWID can attain high treatment adherence, treatment completion, and sustained virologic response in spite of a number of factors typically associated with low adherence and discontinuation of treatment.

A cohort study of treatment-naïve patients in Belgium and the Netherlands reported comparable high HCV treatment completion rates in both drug users $(91.8 \%)$ and nondrug users (93.2\%). Sustained virologic response rates in PWID/noninjecting drug users were around $40 \%$ and did not differ significantly after adjustment for HCV genotype. ${ }^{75}$ Likewise, a French cohort study demonstrated a similar sustained virologic response in active drug users and patients on opioid substitution treatment (58\%) as compared with former $(51 \%)$ and nondrug users $(49 \%)$, despite a more chaotic lifestyle and higher rate of psychiatric comorbidity. ${ }^{76}$ Moreover, in a prospective study comparing sustained virologic response rates in four groups (patients without a history of psychiatric disorders or drug abuse, psychiatric patients, opioid-substituted patients, former drug users), an overall sustained virologic response rate of $58.6 \%$ was found. Sustained virologic response was only associated with genotype and not with patient group, psychiatric diagnosis, depression, antidepressant treatment, sex, or liver enzymes before treatment. ${ }^{77}$ In addition, a high sustained virologic response (86\% in genotype 1 and $100 \%$ in genotype 3 ) in former drug users has been associated with excellent adherence, young age of the patient, early start of HCV treatment, and with a low stage of liver fibrosis. ${ }^{78}$ Perhaps most significantly, high completion (92\%) and sustained virologic response rates $(69 \%)$, comparable with those in nondruguser populations, were also achieved in a well defined sample of comorbid severely opioid-dependent subjects on heroin maintenance treatment. This stresses that, within a needs-adapted treatment setting, HCV treatment may even be extended to difficult-to-treat opioid-dependent patients. ${ }^{79}$ The findings of these individual studies are confirmed by recent systematic reviews. Sustained virologic response in drug users (mean rate 54.3\%; range 18.1\%-94.1\%) was found to be comparable with that among non/ex-users (54\%-63\%), although the efficacy of treatment was found to be lower in drug users with acute $\mathrm{HCV}$, ie, sustained virologic response in drug users of $68.5 \%$ versus $81.5 \%$ in nonusers ${ }^{80}$ Similarly, a high pooled sustained virologic response rate among drug users of 55.5\% (95\% confidence interval 50.6\%-60.3\%) was found in another review, together with a high completion rate of $83.4 \%$ (95\% confidence interval $77.1 \%-88.9 \%$ ), which was higher in addiction-treated patients and in those receiving support services during antiviral therapy. ${ }^{81}$

In contrast, some findings indicate lower treatment adherence and efficacy in drug users as compared with former or nondrug users. This is often associated with altered social functioning, a chaotic lifestyle, and continuation or relapse into drug use. For example, in an Australian sample that consisted predominantly of PWID with recently acquired $\mathrm{HCV}$ infection, sustained virologic response (overall 55\% by intention-to-treat) was negatively associated with reduced social functioning, current opiate pharmacotherapy, and lower adherence, ie, $29 \%$ in nonadherent versus $63 \%$ in adherent with $80 \%$ or more PEG-IFN doses in $80 \%$ of the treatment duration. ${ }^{53,82}$ In San Francisco, CA, USA, although 68\% adherence with HCV treatment was observed in drug users on methadone maintenance treatment, the adherence rate was associated with a sustained virologic response ( $42 \%$ in adherent versus $4 \%$ in nonadherent patients). Moreover, adherence was lower in patients without a period of abstinence before starting HCV treatment and in those who relapsed into drug use during treatment. ${ }^{83} \mathrm{HCV}$ treatment failure has also been associated with liver cirrhosis, depression, and active injecting drug use. ${ }^{36}$

From this abundance of studies, it is evident that a large number of factors can affect treatment adherence and efficacy in PWID. These findings support the suggestion that the decision regarding inclusion or exclusion of PWID from $\mathrm{HCV}$ treatment should be taken on an individual basis for each patient. ${ }^{71}$ Factors that are potentially associated with lower uptake, adherence, and efficacy of treatment in PWID on the patient's side, as well as on the side of treatment professionals and the treatment system, are described in Table 1.

\section{Strategies to overcome barriers to HCV treatment}

Treatment guidelines play a crucial role in initiation of therapy, because they define the current standard of care and provide recommendations on financial coverage by health insurance schemes. In 2005, a systematic literature review of HCV 
Table I Patient-related, provider-related, and system-related factors associated with lower uptake, adherence, and efficacy of HCV treatment in PWID

\begin{tabular}{lll}
\hline Patient-related factors ${ }^{12,53,61,89,90,104,105}$ & Provider-related factors $^{56,87,89,90,104}$ & System-related factors $^{12,54-56,58,59,68,87,89}$ \\
\hline - Chaotic lifestyle and altered social & - Presumption of low adherence & - Lack of integration of addiction \\
functioning & - Concerns regarding relapse and reinfection & treatment and HCV treatment \\
- Psychiatric comorbidity and depression & - Lack of information and counseling for & - Formal high-threshold criteria \\
- HIV coinfection and parallel antiretroviral & drug users & for treatment \\
treatment & - HCV treatment not regarded as "core business" & - Referral-associated delays \\
- Decompensating and relapse into illicit & of drug services & - Gaps in health insurance schemes \\
drug use & - Lack of multidisciplinary approach and team & and budgetary limits of care \\
- Lack of information on HCV infection & composition & Stigmatizing and discrimination \\
and treatment & - Poor management of side effects & against drug users \\
- Perceived low efficacy of HCV treatment & & \\
- Fear of diagnosis, treatment procedures & & \\
- Find side effects & & \\
trancial problems and problems with & & \\
\hline
\end{tabular}

Abbreviations: HCV, hepatitis C virus; HIV, human immunodeficiency virus; PWID, people who inject drugs.

treatment guidelines in the "old" European Union countries and Norway was performed with regard to criteria for inclusion of drug users into treatment. ${ }^{84}$ The authors found considerable differences between countries, ranging from clear disapproval of treatment or the absence of any specific guidelines to recommendations for treatment under specific conditions (eg, a specified period of abstinence from drug use). Only the guidelines in France clearly stressed treatment of active drug users. Given that this review is 8 years old, one might assume that the inclusion criteria in national recommendations have been developed further in the meantime. ${ }^{84}$ However, the current European guidelines still appear rather inconclusive in terms of active drug users. ${ }^{28,85}$ Given the strong evidence in support of the benefits and effectiveness of treating HCV-infected PWID, clear recommendations that tolerate drug use rather than excluding PWID from treatment should be followed. ${ }^{86}$

Naturally, not all HCV-infected PWID are suited to treatment. Pretreatment management and assessment of patients is often used as a measure to manage factors that influence adherence, such as depression, and is also used to test for compliance and clinic attendance. ${ }^{68,77}$ As previously discussed, a wide range of patient-related factors can have an impact on adherence with treatment and its efficacy. Several of these have been associated with sustained virologic response in some studies but not in others. Because of the complexity of factors related to adherence and the efficacy of treatment, clinicians should decide about recruitment into treatment on an individual basis. A future challenge will be to provide guidelines and standardized scales to help clinicians make these individualized assessments more effectively.

With a multidisciplinary approach, potential barriers to recruitment and follow-up of treatment can be addressed effectively. Multidisciplinary teams may consist of addiction specialists, infectious diseases specialists, primary care physicians, nurses, counselors, researchers, and other health or social workers and, if necessary, referral to other professionals outside the treatment center team can be offered. ${ }^{12,50,56,68,87-89}$ A multidisciplinary approach is best applied in a "one-stop-shop" model where various treatments and counseling services are offered in one center. Integrating drug treatment and treatment of HCV (and eventually also human immunodeficiency virus or tuberculosis) in the same center can increase uptake and adherence with therapy. ${ }^{56,90-93}$ HCV counseling, testing, and treatment interventions may be incorporated into drug treatment services with inpatient treatment and opioid substitution programs, because they are more likely to offer $\mathrm{HCV}$ services than outpatient and drug-free programs. ${ }^{94-96}$ As different treatments are offered together, clinicians should take into consideration the interactions between therapies for hepatitis $\mathrm{C}$ and other medication.

Offering medical and mental health services in addition to drug and HCV treatment can help manage the adverse effects of HCV treatment, thereby lowering the barriers to uptake and adherence. A multidisciplinary team may address psychologic side effects, such as depression and emotional lability, or somatic complications, such as hemolytic anemia. ${ }^{97}$ Thus, the success of HCV treatment will depend on the collaboration of experts from various fields to create treatment programs specifically designed for drug users.

Finally, a crucial strategy in overcoming barriers to uptake of HCV treatment is education. Public campaigns, such as the one run for acquired immune deficiency syndrome in the 1990s, are essential to improve knowledge and eliminate 
misconceptions regarding HCV on both the patient's and the provider's side. Australia set an example in this regard. In 2000, a mass media campaign was run and successfully increased public knowledge about the means of transmission of HCV. ${ }^{98}$ Furthermore, it is important to educate people about the availability of HCV screening and treatment and to make these and other services widely available. For instance, research shows that when sterile syringes are easily accessible, PWID readily make use of them. ${ }^{99-101}$ Education could thus also increase HCV screening for individuals with acute HCV. Early treatment uptake is important because the spontaneous clearance rate is limited and, in contrast with chronic $\mathrm{HCV}$, treatment of acute HCV leads to much higher clearance rates ${ }^{102}$ within a shorter period of time. ${ }^{17,103}$ This also applies to PWID. ${ }^{82}$ If drug users were aware of this advantage, they might be more likely and more frequently willing to get tested and thus enable detection of HCV infection at an early stage.

\section{Conclusion}

HCV infection is an important cause of morbidity, mortality, and related social costs. In developed countries, injecting drug use represents the main route of $\mathrm{HCV}$ transmission and yet treatment uptake is low among drug users. HCV treatment has been shown to be efficient in terms of viral clearance and with regard to its potential to prevent further HCV transmissions in the population. The uptake and efficacy of treatment are therefore an important public health issue. Factors associated with poorer treatment outcomes in PWID have been identified on the part of patients, providers, and treatment systems. However, the literature suggests that PWID can achieve treatment adherence and sustained virologic response rates comparable with those of nondrug users. Therefore, drug use per se should not be considered a criterion for exclusion and treatment should be initiated on the basis of an individual assessment of each drug user. Further development of measures leading to higher uptake of treatment and adherence with it, along with appropriate adaptation of treatment guidelines, represent important tools in this regard.

\section{Acknowledgment}

This research was partly funded by the Internal Grant Agency of the Ministry of Health (grant number IGA 10034-4: Social costs of tobacco, alcohol, and illicit drugs in the Czech Republic). The funding body had no role in the review design, collection, analysis, and interpretation of data.

\section{Author contributions}

$\mathrm{VM}$ and BS contributed to the concept and design of the review. VM, BS, LS, JS, VB, TG, and JR participated in identification of the data sources and analysis and interpretation of the findings. VM, BS, LS, JS, VB, TG, and JR contributed to drafting the manuscript. All the authors read and approved the final manuscript.

\section{Disclosure}

The authors have no competing interests in this work.

\section{References}

1. Mohd Hanafiah K, Groeger J, Flaxman AD, Wiersma ST. Global epidemiology of hepatitis $\mathrm{C}$ virus infection: new estimates of agespecific antibody to HCV seroprevalence. Hepatology. 2013;57(4): $1333-1342$.

2. Seeff LB. The history of the "natural history" of hepatitis $C$ (1968-2009). Liver Int. 2009;29 Suppl 1:89-99.

3. World Health Organization. Global burden of disease (GBD) for hepatitis C. J Clin Pharmacol. 2004;44(1):20-29.

4. Alter MJ. Epidemiology of hepatitis C virus infection. World $J$ Gastroenterol. 2007;13(17):2436-2441.

5. Alter MJ. HCV routes of transmission: what goes around comes around. Semin Liver Dis. 2011;31(4):340-346.

6. Urbánek P. Virová hepatitida C. [Hepatitis C virus]. Adiktologie. 2010;10(2):102-109. Czech.

7. Pondé RA. Hidden hazards of HCV transmission. Med Microbiol Immunol. 2011;200(1):7-11. Czech.

8. Aceijas C, Rhodes T. Global estimates of prevalence of $\mathrm{HCV}$ infection among injecting drug users. Int J Drug Policy. 2007;18(5):352-358.

9. Nelson PK, Mathers BM, Cowie B, et al. Global epidemiology of hepatitis B and hepatitis C in people who inject drugs: results of systematic reviews. Lancet. 2011;378(9791):571-583.

10. European Monitoring Centre for Drugs and Drug Addiction; Annual Report 2012. The State of the Drugs Problem in Europe. Luxembourg: Publications Office of the European Union; 2012. Available from: http:// www.emcdda.europa.eu/...cfm/att_190854_EN_TDAC12001ENC_. pdf. Accessed September 1, 2013.

11. Perz JF, Armstrong GL, Farrington LA, Hutin Y, Bell B. The contributions of hepatitis $\mathrm{B}$ virus and hepatitis $\mathrm{C}$ virus infections to cirrhosis and primary liver cancer worldwide. J Hepatol. 2006;45(4): 529-538.

12. Mehta SH, Genberg BL, Astemborski J, et al. Limited uptake of hepatitis $\mathrm{C}$ treatment among injection drug users. J Community Health. 2008;33(3):126-133.

13. Grebely J, Raffa JD, Lai C, et al. Low uptake of treatment for hepatitis C virus infection in a large community-based study of inner city residents. J Viral Hepat. 2009;16(5):352-358.

14. Strathdee S, Latka M, Campbell J, et al. Study to Reduce Intravenous Exposures Project. Factors associated with interest in initiating treatment for hepatitis $\mathrm{C}$ virus (HCV) infection among young $\mathrm{HCV}$-infected injection drug users. Clin Infect Dis. 2005;40 Suppl 5:S304-S312.

15. Iversen J, Topp LJ, Maher L. Australian NSP Survey National Data Report 1995-2010. Sydney, Australia: Faculty of Medicine, The Kirby Institute for Infection and Immunity in Society, University of New South Wales; 2011. Available from: http://www.kirby.unsw.edu. au/node/201260281. Accessed September 1, 2013.

16. Micallef JM, Kaldor JM, Dore GJ. Spontaneous viral clearance following acute hepatitis $\mathrm{C}$ infection: a systematic review of longitudinal studies. J Viral Hepat. 2006;13(1):34-41.

17. Kamal SM. Acute hepatitis C: a systematic review. Am J Gastroenterol. 2008;103(5):1283-1297.

18. van den Berg CH, Grady BP, Schinkel J, et al. Female sex and IL28B, a synergism for spontaneous viral clearance in hepatitis $\mathrm{C}$ virus (HCV) seroconverters from a community-based cohort. PLoS One. 2011;6(11):e27555. 
19. Grebely J, Prins M, Hellard M, et al. International Collaboration of Incident HIV and Hepatitis C in Injecting Cohorts (InC3). Hepatitis C virus clearance, reinfection, and persistence, with insights from studies of injecting drug users: towards a vaccine. Lancet Infect Dis. 2012;12(5): 408-414.

20. Gane E. Future hepatitis C virus treatment: interferon-sparing combinations. Liver Int. 2011;31 Suppl 1:62-67.

21. Davis GL, Alter MJ, El-Serag H, Poynard T, Jennings LW. Aging of hepatitis $\mathrm{C}$ virus (HCV)-infected persons in the United States: a multiple cohort model of HCV prevalence and disease progression. Gastroenterology. 2010;138(2):513-521.

22. John-Baptiste A, Krahn M, Heathcote J, Laporte A, Tomlinson G. The natural history of hepatitis $\mathrm{C}$ infection acquired through injection drug use: meta-analysis and meta-regression. J Hepatol. 2010;53(2): 245-251.

23. Ascione A, Tartaglione T, Di Costanzo GG. Natural history of chronic hepatitis C virus infection. Dig Liver Dis. 2007;39 Suppl 1:S4-S7.

24. Grebely J, Dore GJ. What is killing people with hepatitis C virus infection? Semin Liver Dis. 2011;31(4):331-339.

25. Nizar NZ. Clinical significance of hepatitis $\mathrm{C}$ virus genotypes. Clin Microbiol Rev. 2000;13(2):223-235.

26. Cooreman MP, Schoondermark-Van de Ven EM. Hepatitis C virus: biological and clinical consequences of genetic heterogeneity. Scand J Gastroenterol Suppl. 1996;218:106-115.

27. Nousbaum JB. Genomic subtypes of hepatitis C virus: epidemiology, diagnosis and clinical consequences. Bull Soc Pathol Exot. 1998;91(1): 29-33. French.

28. European Association of the Study of the Liver. 2011 European Association of the Study of the Liver hepatitis C virus clinical practice guidelines. Liver Int. 2012;32 Suppl 1:2-8.

29. Heathcote EJ. Antiviral therapy: chronic hepatitis C. J Viral Hepat. 2007;14 Suppl 1:82-88.

30. Rosen HR. Clinical practice. Chronic hepatitis C infection. $N$ Engl J Med. 2011;364(25):2429-2438

31. Zeuzem S, Buti M, Ferenci P, et al. Efficacy of 24 weeks treatment with peginterferon alfa-2b plus ribavirin in patients with chronic hepatitis $\mathrm{C}$ infected with genotype 1 and low pretreatment viremia. J Hepatol. 2006;44(1):97-103.

32. Jensen DM, Morgan TR, Marcellin P, et al. Early identification of HCV genotype 1 patients responding to 24 weeks peginterferon alpha-2a (40 kd)/ribavirin therapy. Hepatology. 2006;43(5):954-960.

33. Sanchez-Tapias JM, Diago M, Escartín P, et al. Peginterferon-alfa-2a plus ribavirin for 48 versus 72 weeks in patients with detectable hepatitis $\mathrm{C}$ virus RNA at week 4 of treatment. Gastroenterology. 2006;131(2):451- 460.

34. Ferenci P, Laferl H, Scherzer TM, et al. Peginterferon alfa-2a and ribavirin for 24 weeks in hepatitis $C$ type 1 and 4 with rapid virological response. Gastroenterology. 2008;135(2):451-458.

35. Fried MW, Shiffman ML, Reddy KR, et al. Peginterferon alfa-2a plus ribavirin for chronic hepattis C virus infection. $N$ Engl J Med. 2002;347(13):975-982.

36. Alvarez-Uria G, Day JN, Nasir AJ, Russell SK, Vilar FJ. Factors associated with treatment failure of patients with psychiatric diseases and injecting drug users in the treatment of genotype 2 or 3 hepatitis $\mathrm{C}$ chronic infection. Liver Int. 2009;29(7):1051-1055

37. Craine N, Hickman M, Parry JV, et al. Incidence of hepatitis C in drug injectors: the role of homelessness, opiate substitution treatment, equipment sharing, and community size. Epidemiol Infect. 2009;137(9):1255-1265.

38. Gowing L, Farrell MF, Bornemann R, Sullivan LE, Ali R. Oral substitution treatment of injecting opioid users for prevention of HIV infection. Cochrane Database Syst Rev. 2011;8:CD004145.

39. Hagan H, Pouget ER, Des Jarlais DC. A systematic review and metaanalysis of interventions to prevent hepatitis $\mathrm{C}$ virus infection in people who inject drugs. J Infect Dis. 2011;204(1):74-83.

40. Turner KM, Hutchinson S, Vickerman P, et al. The impact of needle and syringe provision and opiate substitution therapy on the incidence of hepatitis $\mathrm{C}$ virus in injecting drug users: pooling of UK evidence. Addiction. 2011;106(11):1978-1988.
41. Vickerman P, Martin NK, Hickman M. Understanding the trends in HIV and hepatitis $\mathrm{C}$ prevalence amongst injecting drug users in different settings - implications for intervention impact. Drug Alcohol Depend. 2012;123(1-3):122-131.

42. Vickerman P, Martin N, Turner K, Hickman M. Can needle and syringe programmes and opiate substitution therapy achieve substantial reductions in hepatitis $\mathrm{C}$ virus prevalence? Model projections for different epidemic settings. Addiction. 2012;107(11):1984-1995.

43. Martin NK, Vickerman P, Foster GR, Hutchinson SJ, Goldberg DJ, Hickman M. Can antiviral therapy for hepatitis $\mathrm{C}$ reduce the prevalence of HCV among injecting drug user populations? A modeling analysis of its prevention utility. J Hepatol. 2011;54(6):1137-1144.

44. Grebely J, Matthews GV, Lloyd AR, Dore GJ. Elimination of hepatitis $\mathrm{C}$ virus infection among people who inject drugs through treatment as prevention: feasibility and future requirements. Clin Infect Dis. June 27, 2013. [Epub ahead of print.]

45. Martin NK, Vickerman P, Hickman M. Mathematical modelling of hepatitis C treatment for injecting drug users. JTheor Biol. 2011;274(1): 58-66.

46. Vickerman P, Martin N, Hickman M. Can hepatitis C virus treatment be used as a prevention strategy? Additional model projections for Australia and elsewhere. Drug Alcohol Depend. 2010;113(2-3):83-85.

47. Zeiler I, Langlands T, Murray JM, Ritter A. Optimal targeting of hepatitis $\mathrm{C}$ virus treatment among injecting drug users to those not enrolled in methadone maintenance programs. Drug Alcohol Depend. 2010;110(3):228-233.

48. Martin NK, Vickerman P, Miners A, et al. Cost-effectiveness of hepatitis $\mathrm{C}$ virus antiviral treatment for injection drug user populations. Hepatology. 2012;55(1):49-57.

49. Hallinan R, Byrne A, Agho K, Dore GJ. Referral for chronic hepatitis $\mathrm{C}$ treatment from a drug dependency treatment setting. Drug Alcohol Depend. 2007;88(1):49-53.

50. Lindenburg CE, Lambers FA, Urbanus AT, et al. Hepatitis C testing and treatment among active drug users in Amsterdam: results from the DUTCH-C project. Eur J Gastroenterol Hepatol. 2011;23(1):23-31.

51. Grebely J, Knight E, Genoway KA, et al. Optimizing assessment and treatment for hepatitis $\mathrm{C}$ virus infection in illicit drug users: a novel model incorporating multidisciplinary care and peer support. Eur $J$ Gastroenterol Hepatol. 2010;22(3):270-277.

52. Harris KA Jr, Arnsten JH, Litwin AH. Successful integration of hepatitis $\mathrm{C}$ evaluation and treatment services with methadone maintenance. J Addict Med. 2010;4(1):20-26.

53. Grebely J, Petoumenos K, Matthews GV, et al. Factors associated with uptake of treatment for recent hepatitis $\mathrm{C}$ virus infection in a predominantly injecting drug user cohort: the ATAHC Study. Drug Alcohol Depend. 2010;107(2-3):244-249.

54. Gazdag G, Horváth G, Szabó O, Ungvari GS. Referral of intravenous drug users for antiviral treatment: effectiveness of hepatitis $\mathrm{C}$ case-finding programmes. Cent Eur J Public Health. 2012;20(3): 223-225.

55. Slezáková S, Okruhlica L. Motivácia na liečbu hepatitídy C u užívatel'ov psychoaktívnych látok. [Motivation for treatment of $\mathrm{HCV}$ infection among drug users]. Adiktologie. 2011;11(3):142-146. Slovak.

56. Grebely J, Genoway K, Khara M, et al. Treatment uptake and outcomes among current and former injection drug users receiving directly observed therapy within a multidisciplinary group model for the treatment of hepatitis C virus infection. Int J Drug Policy. 2007;18(5): 437-443.

57. Hopwood M, Treloar C. The drugs that dare not speak their name: injecting and other illicit drug use during treatment for hepatitis $\mathrm{C}$ infection. Int J Drug Policy. 2007;18(5):374-380.

58. Mimiaga MJ, Safren SA, Dvoryak S, Reisner SL, Needle R, Woody G. "We fear the police, and the police fear us": structural and individual barriers and facilitators to HIV medication adherence among injection drug users in Kiev, Ukraine. AIDS Care. 2010;22(11):1305-1313.

59. Sarang A, Rhodes T, Sheon N, Page K. Policing drug users in Russia: risk, fear, and structural violence. Subst Use Misuse. 2010;45(6): 813-864. 
60. Cooper CL, Giordano C, Mackie D, Mills EJ. Equitable access to HCV care in HIV-HCV co-infection can be achieved despite barriers to health care provision. Ther Clin Risk Manag. 2010;6:207-212.

61. Grebely J, Oser M, Taylor LE, Dore GJ. Breaking down the barriers to hepatitis $\mathrm{C}$ virus (HCV) treatment among individuals with HCV/HIV coinfection: action required at the system, provider, and patient levels. J Infect Dis. 2013;207 Supp1 1:S19-S25.

62. Tungol A, Rademacher K, Schafer JA. Formulary management of the protease inhibitors boceprevir and telaprevir for chronic hepatitis $\mathrm{C}$ virus. J Manag Care Pharm. 2011;17(9):685-694.

63. Assis DN, Lim JK. New pharmacotherapy for hepatitis C. Clin Pharmacol Ther. 2012;92(3):294-305.

64. Rockstroh J. New agents for hepatitis $\mathrm{C}$ and the challenges in treating co-infected patients. J Int AIDS Soc. 2012;15(6):18115.

65. Sylvestre DL, Clements BJ, Malibu Y. Cannabis use improves retention and virological outcomes in patients treated for hepatitis C. Eur $J$ Gastroenterol Hepatol. 2006;18(10):1057-1063.

66. Myles A, Mugford GJ, Zhao J, Krahn M, Wang PP. Physicians' attitudes and practice toward treating injection drug users with hepatitis $\mathrm{C}$ : results from a national specialist survey in Canada. Can J Gastroenterol. 2011;25(3):135-139.

67. Litwin AH, Kunins HV, Berg KM, et al. Hepatitis C management by addiction medicine physicians: results from a national survey. $J$ Subst Abuse Treat. 2007;33(1):99-105.

68. Mravčík V. Léčba VHC u injekčních uživatelů drog v ČR - průzkum mezi centry pro léčbu virových hepatitid. [HCV Treatment of Injecting Drug Users in the Czech Republic - Survey among Viral Hepatitis Treatment Centres]. Adiktologie. 2012;12(1): 10-22. Czech.

69. Dalgard O, Bjoro K, Hellum K, et al. Treatment of chronic hepatitis C in injecting drug users: 5 years' follow-up. Eur Addict Res. 2002;8(1): $45-49$.

70. Grebely J, Pham ST, Matthews GV, et al. Hepatitis C virus reinfection and superinfection among treated and untreated participants with recent infection. Hepatology. 2011;55(4):1058-1069.

71. Edlin BR. Prevention and treatment of hepatitis $\mathrm{C}$ in injection drug users. Hepatology. 2002;36(5 Suppl 1):S210-S219.

72. Hartz A, He T. Why is greater medication adherence associated with better outcomes. Emerg Themes Epidemiol. 2013;10(1):1.

73. Weiss JJ, Brau N, Stivala A, Swan T, Fishbein D. Review article: adherence to medication for chronic hepatitis $\mathrm{C}$-building on the model of human immunodeficiency virus antiretroviral adherence research. Aliment Pharmacol Ther. 2009;30(1):14-27.

74. Grebely J, Matthews GV, Hellard M, et al; ATAHC Study Group. Adherence to treatment for recently acquired hepatitis $\mathrm{C}$ virus (HCV) infection among injecting drug users. J Hepatol. 2011;55(1): $76-85$.

75. Robaeys G, Van Vlierberghe H, Mathei C, et al. Similar compliance and effect of treatment in chronic hepatitis $\mathrm{C}$ resulting from intravenous drug use in comparison with other infection causes. Eur J Gastroenterol Hepatol. 2006;18(2):159-166.

76. Melin P, Chousterman M, Fontanges T, et al. Effectiveness of chronic hepatitis $\mathrm{C}$ treatment in drug users in routine clinical practice: results of a prospective cohort study. Eur J Gastroenterol Hepatol. 2010;22(9):1050-1057.

77. Schaefer M, Hinzpeter A, Mohmand A, et al. Hepatitis C treatment in "difficult-to-treat" psychiatric patients with pegylated interferonalpha and ribavirin: response and psychiatric side effects. Hepatology. 2007;46(4):991-998.

78. Gazdik F, Gazdikova K, Laktis K, et al. High virologic sustained response for former young intravenous drug users with chronic hepatitis $\mathrm{C}$ treated by pegylated interferon-alpha plus ribavirin. Bratisl Lek Listy. 2009;110(2):77-84.

79. Schulte B, Schütt S, Brack J, et al. Successful treatment of chronic hepatitis $C$ virus infection in severely opioid-dependent patients under heroin maintenance. Drug Alcohol Depend. 2010;109(1-3):248-251.
80. Hellard M, Sacks-Davis R, Gold J. Hepatitis C treatment for injection drug users: a review of the available evidence. Clin Infect Dis. 2009;49(4):561-573.

81. Dimova RB, Zeremski M, Jacobson IM, Hagan H, Des Jarlais DC, Talal AH. Determinants of hepatitis $\mathrm{C}$ virus treatment completion and efficacy in drug users assessed by meta-analysis. Clin Infect Dis. 2012;55(6):806-816.

82. Dore GJ, Hellard M, Matthews GV, et al. Effective treatment of injecting drug users with recently acquired hepatitis $\mathrm{C}$ virus infection. Gastroenterology. 2010;138(1):123-135.

83. Sylvestre DL, Clements BJ. Adherence to hepatitis C treatment in recovering heroin users maintained on methadone. Eur J Gastroenterol Hepatol. 2007;19(9):741-747.

84. Reimer J, Schulte B, Castells X, et al. Guidelines for the treatment of hepatitis $\mathrm{C}$ virus infection in injection drug users: status quo in the European Union countries. Clin Infect Dis. 2005;40 Suppl 5:373-378.

85. Calvaruso V, Craxi A. European Association of the Study of the Liver hepatitis C virus clinical practice guidelines. Liver Int. 2012;32 Suppl 1: 2-8.

86. Robaeys G, Grebely J, Mauss S, et al; International Network on Hepatitis in Substance Users. Recommendations for the management of hepatitis $\mathrm{C}$ virus infection among people who inject drugs. Clin Infect Dis. 2013;57 Supp1 2:S129-S137.

87. Backmund M, Meyer K, Von Zielonka M, Eichenlaub D. Treatment of hepatitis C infection in injection drug users. Hepatology. 2001;34(1): 188-193.

88. Reimer J, Haasen C. Need-adapted HCV-treatment setting for injection drug users. Lancet. 2009;373(9681):2090-2091.

89. Nguyen OK, Dore GJ, Kaldor JM, Hellard ME. Recruitment and follow-up of injecting drug users in the setting of early hepatitis C treatment: Insights from the ATAHC study. Int J Drug Policy. 2007;18(5): 447-451.

90. Treloar C, Newland J, Rance J, Hopwood M. Uptake and delivery of hepatitis $\mathrm{C}$ treatment in opiate substitution treatment: perceptions of clients and health professionals. J Viral Hepat. 2010;17(12): 839-844.

91. Teasdale KE, Keren KM, Kiel A, Becker K. Improving services for prevention and treatment of substance misuse for Aboriginal communities in a Sydney Area Health Service. Drug Alcohol Rev. 2008;27(2):152-159.

92. Litwin AH, Soloway I, Gourevitch MN. Integrating services for injection drug users infected with hepatitis $\mathrm{C}$ virus with methadone maintenance treatment: challenges and opportunities. Clin Infect Dis. 2005;40 Suppl 5:S339-S345.

93. Moussalli J, Delaquaize H, Boubilley D, et al. Factors to improve the management of hepatitis $\mathrm{C}$ in drug users: an observational study in an addiction centre. Gastroenterol Res Pract. 2010;2010:pii261472.

94. Hagan H, Strauss SM, Astone JM, Des Jarlais DC. Medical examinations at entry to treatment for drug abuse as an opportunity to initiate care for hepatitis C virus infection. Clin Infect Dis. 2005;40 Suppl 5: S297-S303.

95. Strauss SM, Astone J, Vassilev ZP, Des Jarlais DC, Hagan H. Gaps in the drug-free and methadone treatment program response to hepatitis $\mathrm{C}$. J Subst Abuse Treat. 2003;24(4):291-297.

96. Strauss SM, Falkin GP, Vassilev Z, Des Jarlais DC, Astone J. A nationwide survey of hepatitis $\mathrm{C}$ services provided by drug treatment programs. J Subst Abuse Treat. 2002;22(2):55-62.

97. Edlin BR, Seal KH, Lorvick J, et al. Is it justifiable to withhold treatment for hepatitis C from illicit-drug users? N Engl J Med. 2001;345(3): 211-215.

98. Smith BJ, Bauman AE, Chen J, et al. Hepatitis C in Australia: impact of a mass media campaign. Am J Prev Med. 2006;31(6):492-498.

99. Watters JK, Estilo MJ, Clark GL, Lorvick J. Syringe and needle exchange as HIV/AIDS prevention for injection drug users. JAMA. 1994;271(2):115-120. 
100. Bluthenthal RN, Kral AH, Erringer EA, Edlin BR. Use of an illegal syringe exchange and injection-related risk behaviors among streetrecruited injection drug users in Oakland, California, 1992-1995. J Acquir Immune Defic Syndr Hum Retrovirol. 1998;18(5):505-511.

101. Bluthenthal RN, Kral AH, Gee L, Erringer EA, Edlin BR. The effect of syringe exchange use on high-risk injection drug users: a cohort study. AIDS. 2000;14(5):605-611.

102. Gerlach JT, Diepolder HM, Zachoval R, et al. Acute hepatitis C: high rate of both spontaneous and treatment-induced viral clearance. Gastroenterology. 2003;125(1):80-88.
103. Wiegand J, Buggisch P, Boecher W, et al. Early monotherapy with pegylated interferon alpha-2b for acute hepatitis $\mathrm{C}$ infection: the HEP-NET acute-HCV-II study. Hepatology. 2006;43(2):250-256.

104. Grebely J, Genoway KA, Raffa JD et al. Barriers associated with the treatment of hepatitis C virus infection among illicit drug users. Drug and Alcohol Dependence. 2008;93;(1-2):141-147.

105. Schaefer M, Mauss S. Hepatitis C treatment in patients with drug addiction: clinical management of interferon-alpha-associated psychiatric side effects. Curr Drug Abuse Rev. 2008;(2):177-187.

\section{Publish your work in this journal}

Patient Preference and Adherence is an international, peer-reviewed, open access journal focusing on the growing importance of patient preference and adherence throughout the therapeutic continuum. Patient satisfaction, acceptability, quality of life, compliance, persistence and their role in developing new therapeutic modalities and compounds to optimize clinical outcomes for existing disease states are major areas of interest. This journal has been accepted for indexing on PubMed Central. The manuscript management system is completely online and includes a very quick and fair peer-review system. Visit http://www.dovepress.com/ testimonials.php to read real quotes from published authors.

Submit your manuscript here: http://www.dovepress.com/patient-preference-and-adherence-journal 